Article

\title{
Spatial Pattern Dynamics Analysis at Coastal Area Using Spatial Metric in Pekalongan, Indonesia
}

\author{
Ali Wijaya ${ }^{1,}{ }^{*}$, Cahyono Susetyo ${ }^{1}$, Azillatin Q. Diny ${ }^{1}$, Danika H. Nabila ${ }^{1}$, Rahel P. Pamungkas ${ }^{1}$, \\ Mohammad Hadikunnuha ${ }^{2}$, and Nursakti A. Pratomoatmojo ${ }^{1}$ \\ 1 Department of Urban and Regional Planning, Institut Teknologi Sepuluh Nopember, Surabaya 60111, \\ Indonesia; tu_pwk@its.ac.id \\ 2 Department of Geomatic Engineering, Institut Teknologi Sepuluh Nopember, Surabaya 60111, Indonesia; \\ geomatika@its.ac.id \\ * Correspondence: ali.wijaya13@mhs.urplan.its.ac.id; Tel.: +63-857-498-26432
}

\begin{abstract}
Pekalongan is one of several cities that lies in the northern coast of Java island which is often flooded due to sea level rise. This condition impacted its urban development characteristic and increase in the future. In this research both Geographical Information System based and Spatial Metric approach are used. The spatial pattern is analyzed by using spatial metric based on the exploration of land use change that occurred. In this research, the spatial pattern is focused on aggregation pattern and diversity in coastal area. The result shows that the land use of coastal area are dominated with swamp, then followed by settlement and fishpond. It is also shown that the greatest land use change occurred on paddy field and swamp areas. Based on the spatial metric calculation, the aggregation level of land use decrease periodically and has a small growth level. It is indicated from its metric value aggregation and diversity from two periods: 2003-2009 and 20092016. Overall the land use of Pekalongan experienced large dynamics, especially in its coastal area. The spatial pattern trend in those area tend to be more sprawl as defined by the decrease of aggregation pattern and low level of land use growth pattern.
\end{abstract}

Keywords: spatial pattern; land use; spatial metric; aggregation; diversity

\section{Introduction}

Spatial element is something that must be considered in every region's development planning. Spatial information shows the function of a location or a region. The usage of spatial analysis has been developed for locational based analysis by using GIS (Geographical Information System). One of many output that can be used as a consideration material in policy decision making is spatial model. The computer-based model of land use change and urban growth has become an important tool to support regional planning [1][2]. One process that indicates the development of a region is the change of land use which is dynamic and can be observed with multi-temporal spatial analysis. Both regional and urban planning always receive great attention in recent decades, especially the ability to form landscape constantly [3][4]. The complexity and urban development can be characterized by the complexity of spatial patterns and land use. Spatial vision area is always directed by the shape and spatial distribution that is ideal for its landscape [5] and to understand it spatial analysis is needed.

Spatial metric has been known as a spatial analysis which is related with the spatial development in urban area. It is defined as a measurement which is derived from digital-based thematic map analysis that shows the spatial heterogeneity at certain scale and resolution [2]. Spatial metric is also known as a quantitative approach that can be used to assess spatial characteristic of land use and urban structure. When spatial metric is being used for multi temporal, it could describe the level of spatial heterogeneity level in certain time [6]. Spatial metric is also known as a an accurate approach to interpret spatial pattern in land use change since it could provide additional information about the structure of change ad could be continued with land use change modelling [7]. As a result, the spatial 
pattern that are derived from the interpretation of spatial metric, such as density pattern and accretion of land use, shows the development level of an area which led to the urgency to the usage of spatial analysis.

Pekalongan is a city in Central Java Province Indonesia which is located in the northern coast of Java Island. Tidal flood has become an important issues since it is often occurred in this city as a result of sea level rise [8][9][10][11][12]. Tidal flood is the most serious threat from sea level rise that can only be reduced impact [13]. Because of this phenomenon, the land use change in Pekalongan has been also affected [14]. Land use change in a landscape is driven by driving force factors [15][16] such as sea level rise in Pekalongan. Even though, in general, the land use of Pekalongan has not been affected, shifts in function and usage of land have been identified, e.g. land use for paddy field has been decreasing significantly [17]. Thus, it indicates that productive land has been dominating the shift of function since one of land's characteristics is vulnerable of natural phenomenon such as sea level rise [18]. If it is associated with the trend of climate change, the impact of sea level rise will be even greater [19] including in Pekalongan [20]. Based on the previous study [21], the tidal flood model of Pekalongan has predicted that $50,68 \%$ of the whole area will be flooded by the year 2030 . Tidal flood has been also noticed as one of several factors that caused the land use change of Pekalongan during 2003-2009 [21]. This condition led to a fragmentation pattern and non-optimum mixed land use which are Pekalongan's development characteristics. Therefore, the accuracy of land use and its management in Pekalongan has become an urgency to be considered in planning process [22] to minimize the risk from natural disaster, such as tidal flood [10]. Thus, regarding this situation an analysis on land use change and spatial pattern by using spatial approach is needed in order to understand and optimize the development of Pekalongan.

\section{Materials and Methods}

\subsection{Study Area}

This research took place in the coastal area of Pekalongan, which geographically lays between 6050'42"-6055'44" LS and 109o37'55 "-109o42'19" BT. Located in the province of Central Java Indonesia, Pekalongan has a total area of 4,525 hectares, or about $0.14 \%$ of the area of Central Java Province. Administratively, Pekalongan is consisted of 4 districts, with 1 district in coastal area. The coastal district itself is consisted of 7 villages [23]. According to its elevation, Pekalongan is classified as a lowland area: 1 meter of land between the region of the north to the highest 6 meters above sea level in the southern region. The average slope percentage is between $0-5 \%$ which is considered relatively flat. Physically, Pekalongan is considered as a city which is prone to disasters, such as tidal flood. The tidal flood in Pekalongan occurred almost every day when the tide is going high [14] . This phenomenon led to infrastructure damages and also impacted social and economic life of local communities. Above all, the existing land use of Pekalongan is the most impacted aspect.

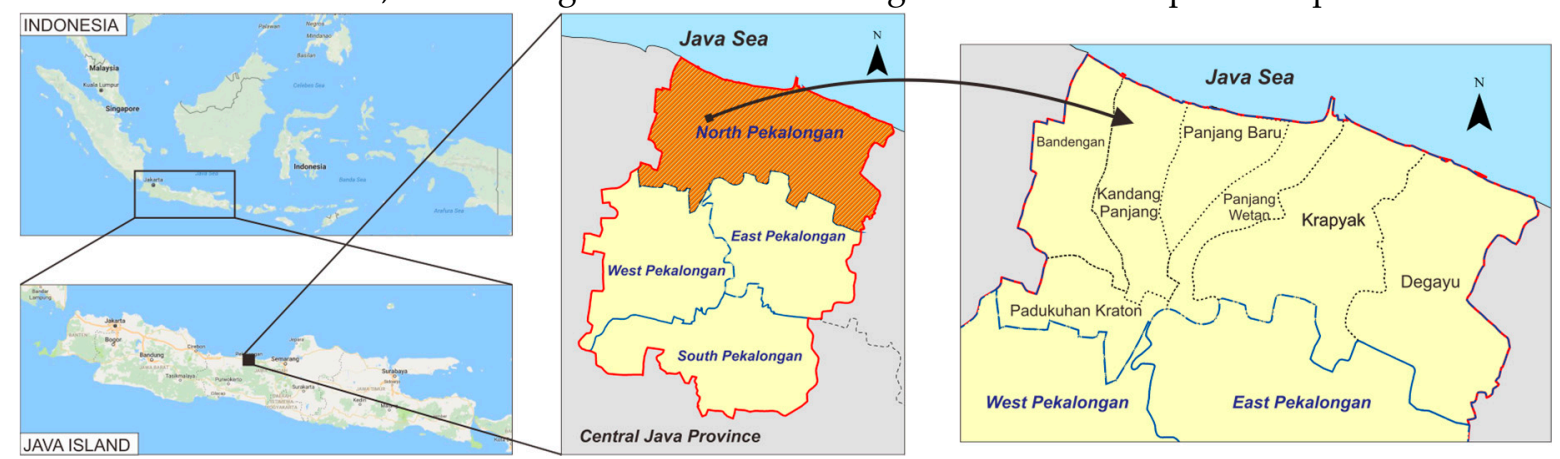

Figure 1. Location of the study area in Pekalongan, Indonesia

Study area is on North Pekalongan which is a coastal area directly adjacent to the sea. All areas in North Pekalongan have low elevation characteristics and are vulnerable to flooding by sea level 
rise. Each village area in North Pekalongan is an area affected by sea level rise. Here for the village in the study area.

Table 1. Villages administration in North Pekalongan

\begin{tabular}{lll}
\hline VILLAGES & AREA (Ha) & PERCENTAGE (\%) \\
\hline Bandengan & 193.53 & 12.57 \\
Degayu & 400.86 & 26.04 \\
Kandang Panjang & 182.10 & 11.83 \\
& & \\
Krapyak & 358.38 & 23.28 \\
Padukuhan Kraton & 137.66 & 8.94 \\
Panjang Baru & 132.32 & 8.59 \\
Panjang Wetan & 134.67 & 8.75 \\
\hline TOTAL & $\mathbf{1 5 3 9 . 5 3}$ & $\mathbf{1 0 0 . 0 0}$ \\
\hline
\end{tabular}

\subsection{Data}

In this study, the required data is geospatial data in Pekalongan with multi-temporal dimensions. Data that used focused on the aim to determine the spatial pattern of land use in the coastal area of Pekalongan. Land use data were obtained from high resolution Digital Globe's Quickbird imageries with acquisition date at 2003, 2009, and 2016. Then the phenomenon of tidal flood as the driving factor of land use change was observed directly with the primary survey. Data and sources used can be seen in the following table.

Table 2. A set of geospatial data and source

\begin{tabular}{lll}
\hline DATA & SOURCE OF DATA & DATE \\
\hline Administrative Boundary Map & Statistics of Pekalongan & $2003,2009,2016$ \\
Sattelite Imageries Pekalongan & Digital Globe's Quickbird & $2003,2009,2016$ \\
Digital Elevation Model & Topographic Map of Indonesia (RBI) & 2001 \\
Tidal flood & Primary survey & 2016 \\
\hline
\end{tabular}

\subsection{Land Use Change Mapping}

This process itself require land use data from different time dimension (multi-temporal), which are data from 2003, 2009, and 2016 that were obtained from Quickbird imageries interpretation which were classified into different land use types, based on its homogenous appearance, by using Geographical Information System (GIS). Quickbird imageries that has been set for the coordinate system can be manually delineated land use with the visual interpretation techniques [24] based on their characteristics. Classification of land use in this study is more directed at supervised classification. After this step is done, the next step is validation which is done through ground checking. The ground checking step is then followed with a process that compares the land use change from 3 periods $(2003,2009$, and 2016) through overlay analysis. The result of land use change mapping analysis is showing the dynamics of land change in coastal area of Pekalongan which is characteristic of flooded area of sea level rise.

\subsection{Spatial Patterns Analysis of Land Use by Spatial Metric}

This analysis proceed the result from land use change mapping by using a method called spatial metric resulting spatial pattern of Pekalongan coastal area's land use. Spatial metric itself is a method that allows user to formulate metrics-based dynamic spatial pattern. The spatial pattern dynamics of land use that are identified in a multi temporal manner are spatial patterns in the period 2003-2009 and 2009-2016. In this study, the analysis process is conducted by using the ArcGIS 10.4 software, combined with Fragstats 4.2 [25]. The output of this analysis are calculation result and chart, which could be described further in accordance with the development of Pekalongan, both its physical 
aspect and spatial pattern such as fragmentation and diversity pattern. Fragmentation pattern indicates aggregation level of land use, will know the trend of density value in coastal area of Pekalongan. Then diversity pattern will indicate the level of land use growth of the tendency of diversity value in each period. From these results will be identified spatial patterns of the landscape as a whole on the coastal area of Pekalongan.

\subsection{Selection of Metrics}

Spatial pattern is something that shows the placement or arrangement of objects on the surface of the earth [26]. The spatial pattern in this study focuses on multi-temporal patterns of fragmentation and diversity in landscape level (coastal area of Pekalongan). It is used as a variable to analyze the spatial pattern based on the fragmentation and diversity categories [27] which is adjusted based on the purpose of this research and calculated with the tools from Fragstats. The type metric is as follow:

Table 3. The type of metrics used

\begin{tabular}{|c|c|c|c|c|}
\hline CATEGORY & METRIC & CALCULATION DESCRIPTION & UNIT & RANGE \\
\hline \multirow[t]{4}{*}{ Fragmentation } & $\begin{array}{l}\text { Number of Patches } \\
(N P)\end{array}$ & $\begin{array}{l}\text { NP equals the number of patches in the } \\
\text { landscape }\end{array}$ & None & $\begin{array}{l}\mathrm{NP} \geq 1 \\
\text { no limit }\end{array}$ \\
\hline & Patch Density (PD) & $\begin{array}{l}\text { PD equals the number of patches in the } \\
\text { landscape divided by total landscape area }\end{array}$ & $\begin{array}{l}\text { Number } \\
\text { per } 100 \\
\text { hectares }\end{array}$ & $\begin{array}{l}\mathrm{PD}>0 \\
\text { no limit }\end{array}$ \\
\hline & $\begin{array}{l}\text { Interpersion and } \\
\text { Juxtaposition Index } \\
\text { (IJI) }\end{array}$ & $\begin{array}{l}\text { IJI equals minus the sum of the length }(\mathrm{m}) \\
\text { of each unique edge type divided by the } \\
\text { total landscape edge }(\mathrm{m}) \text {, multiplied by the } \\
\text { logarithm of the same quantity, summed } \\
\text { over each unique edge type; divided by the } \\
\text { logarithm of the number of patch types } \\
\text { times the num ber of patch types minus } 1 \\
\text { divided by } 2 \text {; multiplied by } 100 \text { (to convert } \\
\text { to a percentage). }\end{array}$ & Percent & $0>\mathrm{IJI} \leq 100$ \\
\hline & $\begin{array}{l}\text { Percentage of Like } \\
\text { Adjacencies (PLADJ) }\end{array}$ & $\begin{array}{l}\text { PLADJ equals the number of like } \\
\text { adjacencies involving the focal class, } \\
\text { divided by the total number of cell } \\
\text { adjacencies involving the focal class; } \\
\text { multiplied by } 100 \text { (to convert to a } \\
\text { percentage). }\end{array}$ & Percent & $0 \leq \mathrm{PLADJ} \leq 100$ \\
\hline \multirow[t]{2}{*}{ Diversity } & $\begin{array}{l}\text { Shannon's Diversity } \\
\text { Index (SHDI) }\end{array}$ & $\begin{array}{l}\text { SHDI equals minus the sum, across all } \\
\text { patch types, of the proportional abundance } \\
\text { of each patch type multiplied by that } \\
\text { proportion. }\end{array}$ & None & $\begin{array}{l}\text { SHDI } \geq 1 \\
\text { no limit }\end{array}$ \\
\hline & $\begin{array}{l}\text { Shannon's Evenness } \\
\text { Index (SHEI) }\end{array}$ & $\begin{array}{l}\text { SHEI equals minus the sum, across all } \\
\text { patch types, of the proportional abundance } \\
\text { of each patch type multiplied by that } \\
\text { proportion, divided b y the logarithm of } \\
\text { the number of patch types. }\end{array}$ & None & $0 \leq \mathrm{SHEI} \leq 1$ \\
\hline
\end{tabular}

Each metric has its own formula and interpretation. The formula of each type of metric is a way to identify the spatial pattern in the accordance with the function of the metric itself. For the algorithm's calculation in each metric, sourced from McGarigal et al [28]. The results of the spatial analysis of this metric in the form of statistical calculations that can be used as a comparison chart of spatial patterns of land use. 


\section{Results}

\subsection{Spatio-Temporal Landuse Mapping}

Land use mapping is used to determine the spatio temporal dynamics of land use that is occurred. Land use map in this study used the interpretation of the Quickbird satellite imageries on 2003, 2009, and 2016. Quickbird imageries has resolution up to 0,6 m, the imagery provides detail resolution and fits with the needs of this research. The process of land use classification of the image in this study using a digitation on screen with GIS based on the visual interpretation of the satellite imagery to be the land use class vector. From the type of land use classification and the characteristics of each type of land use that could be identified, digitization has been done with a depth of 1: 10000 scale to become raster data with $5 \mathrm{M}$ resolution. The use of $5 \times 5$ meter resolution takes into account to the level of detailed land use and already covers the smallest land use area in the study area. Land use maps from previous period are adapted from a previous study in Pekalongan [21] and interviews with local inhabitants. Below is a map of multi-temporal land use in the coastal area of Pekalongan.
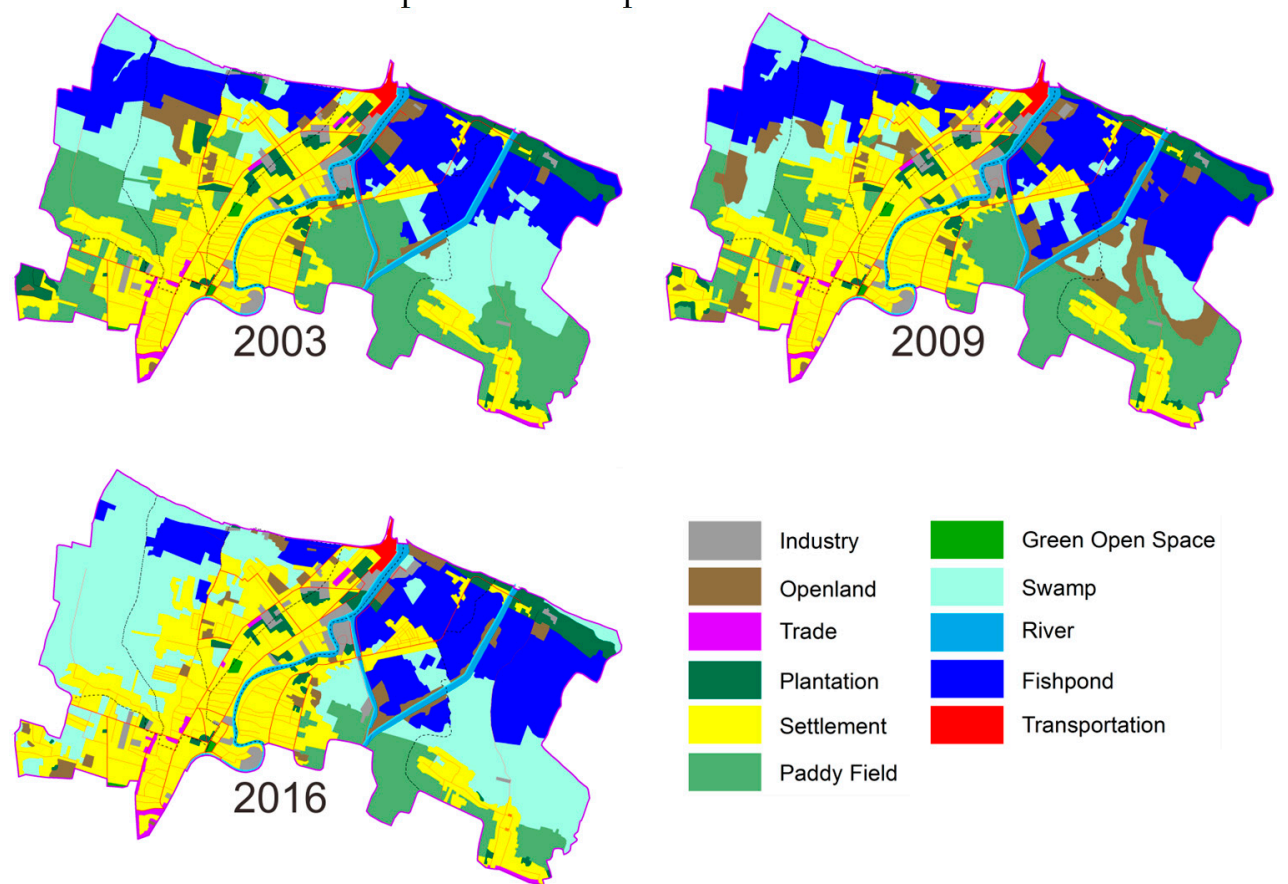

Figure 2. Multi-temporal land use map of study area

The map above shows the dynamics of land use. Changes in the area of multi temporal land use show the characteristics of Pekalongan's coastal area, which has the driving force in the form sea level rise. The statistics changes of the coastal area's land use could be seen as follow:

Table 4. Statistics of land use area in study area

\begin{tabular}{lllllll}
\hline \multirow{2}{*}{ LAND USE CLASS } & \multicolumn{2}{l}{ LAND USE AREA (Ha) } & \multicolumn{2}{l}{ LAND USE CHANGE (Ha) } \\
\cline { 2 - 7 } & $\mathbf{2 0 0 3}$ & $\mathbf{2 0 0 9}$ & $\mathbf{2 0 1 6}$ & $\mathbf{2 0 0 3 - 2 0 0 9}$ & $\mathbf{2 0 0 9 - 2 0 1 6}$ & $\mathbf{2 0 0 3 - 2 0 1 6}$ \\
\hline Industry & 35.00 & 38.31 & 42.29 & 3.31 & 3.98 & 7.29 \\
\hline Openland & 51.13 & 126.25 & 50.13 & 75.12 & -76.11 & -0.99 \\
\hline Trade & 10.91 & 11.13 & 12.21 & 0.21 & 1.08 & 1.29 \\
\hline Plantation & 83.49 & 69.33 & 58.15 & -14.17 & -11.17 & -25.34 \\
\hline Settlement & 419.66 & 450.30 & 469.86 & 30.64 & 19.56 & 50.20 \\
\hline Paddy Field & 351.06 & 281.97 & 95.96 & -69.10 & -186.00 & -255.10 \\
\hline Swamp & 252.84 & 163.01 & 484.29 & -89.83 & 321.29 & 231.46 \\
\hline Green Open Space & 3.21 & 3.21 & 3.21 & 0.00 & 0.00 & 0.00 \\
\hline
\end{tabular}




\begin{tabular}{lllllll}
\hline \multirow{2}{*}{ LAND USE CLASS } & \multicolumn{3}{l}{ LAND USE AREA (Ha) } & \multicolumn{3}{l}{ LAND USE CHANGE (Ha) } \\
\cline { 2 - 7 } & $\mathbf{2 0 0 3}$ & $\mathbf{2 0 0 9}$ & $\mathbf{2 0 1 6}$ & $\mathbf{2 0 0 3 - 2 0 0 9}$ & $\mathbf{2 0 0 9 - 2 0 1 6}$ & $\mathbf{2 0 0 3 - 2 0 1 6}$ \\
\hline River & 40.30 & 40.30 & 40.30 & 0.00 & 0.00 & 0.00 \\
\hline Fishpond & 283.63 & 347.45 & 274.83 & 63.81 & -72.62 & -8.81 \\
\hline Transportation & 7.67 & 7.67 & 7.67 & 0.00 & 0.00 & 0.00 \\
\hline
\end{tabular}

From the statistics it could be inferred that Pekalongan's coastal area experienced such dynamic significant changes. The most dominant land use in 2016 in North Pekalongan is swamp area, which increased rapidly compared to the previous period, which reach 321,29 Ha. The widespread characteristic of swamps in coastal areas of Pekalongan indicates the dominant impact of sea level rise. The second largest land use is settlement area, which increased on each period but it tends to be small for the addition of breadth. Thirdly, there is paddy field, which decreased significantly. From 2003 to 2006, the wide of agricultural land in coastal area of Pekalongan has reduced by 255, 10 Ha due to its water imundation from sea level rise. So that from the dynamics of land use in Pekalongan's coastal area it could be inferred that the formed spatial pattern is related with the tendency level of fragmentation and diversity in Pekalongan's coastal area.

\subsection{Aggregation Pattern Metric}

Spatial patterns which analyzed for dynamics include spatial land use aggregation that is calculated in landscape level. Metric aggregation calculation also used the multi temporal land use data in the form of raster. The level of land use density in coastal area of Pekalongan has its own characteristic due to the phenomenon of tidal flood from sea level rise that occured. This is a driving factor for changes in land use that will certainly affect the level of urban aggregation form. The simulation result shows the calculation of metric for each year and will know the dynamics of spatial pattern of land use density.

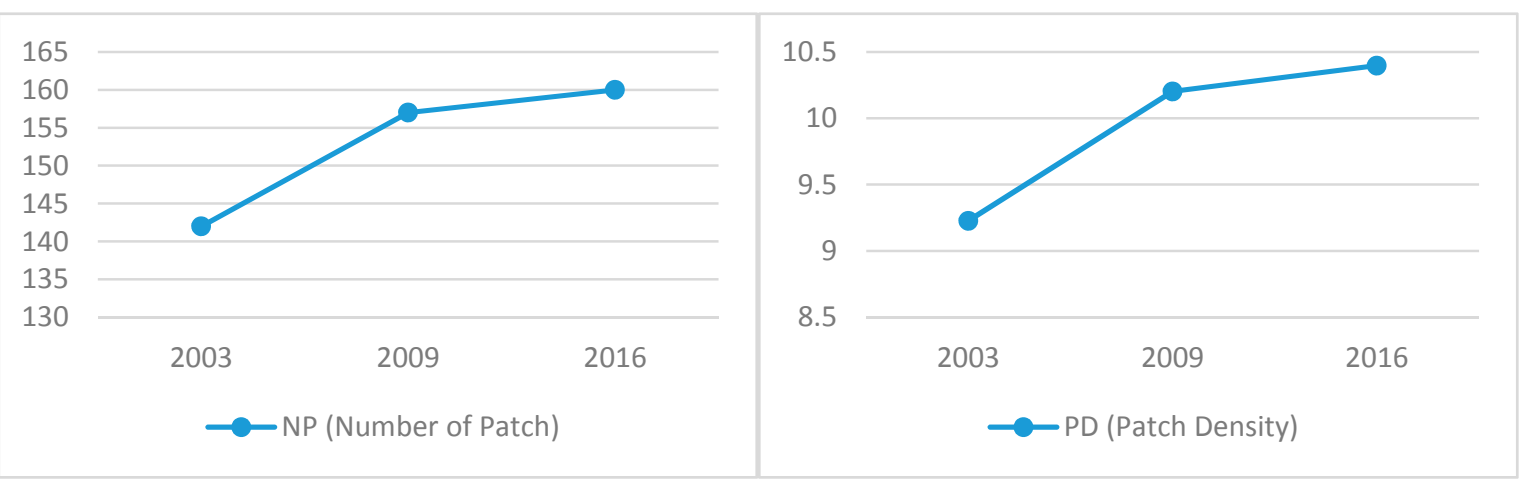

(a)

(b)

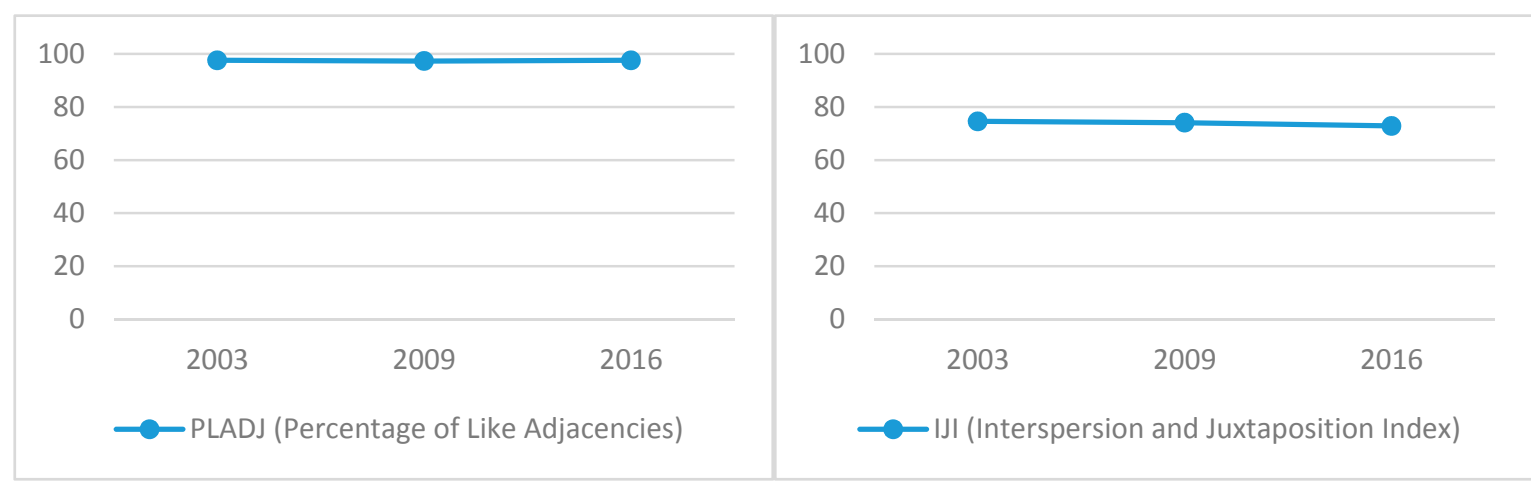

(c)

(d)

Figure 3. Aggregation pattern metric dynamics in landscape, (a) Number of Patch, (b) Patch Density, (c) Percentage of Like Adjacencies, (d) Interspersion and Juxtaposition Index 
From the results of these calculations, it can be known for dynamic patterns of aggregation in the period 2003, 2009, and 2016 in Pekalongan coastal region that includes NP, PD, PLADJ, and IJI. The value of NP in the coastal areas of Pekalongan in every period always increases the patch with total in the period 2003-2016 added until 18 patches. Number of Patch (NP) is a metric measurement of spatial density patterns which calculated from the number of patches. The greater of NP value, indicating the greater of the fragmentation of the type of use that occurs. The PD value of statistic is equal to the NP, increasing the patch density value for each period. PD in 2003 has a value of 9.23 patch/100ha to 10.4 patch/100ha in 2016. PD is a metric that measures the density and level of fragmentation of land use or the area scope of the patch density. The bigger PD value, the less spatial density of land use. Then the value of PLADJ in each period tend to be static and experience to the dynamics of a very small value that is under 1\%. PLADJ is a metric of measurement for the level of patch type aggregation on each type of land use which shows the percentage of cohesiveness of land use. Furthermore, the value of IJI shows a decrease in value, but relatively small. For the reduction of IJI value for the period 2003-2016 is under $2 \%$. IJI is the calculation of the dispersed index value of land use in a landscape.

The coastal area of Pekalongan has characteristics in accordance with the dynamics of metric aggregation values that have been analyzed. Furthermore, each village area in Pekalongan's coastal area will have its own characteristics which then form an area and affect to composition of aggregation in the coastal area of Pekalongan. All coastal villages in the Pekalongan are areas affected by sea level rise and this makes clear the impact on land use patterns.

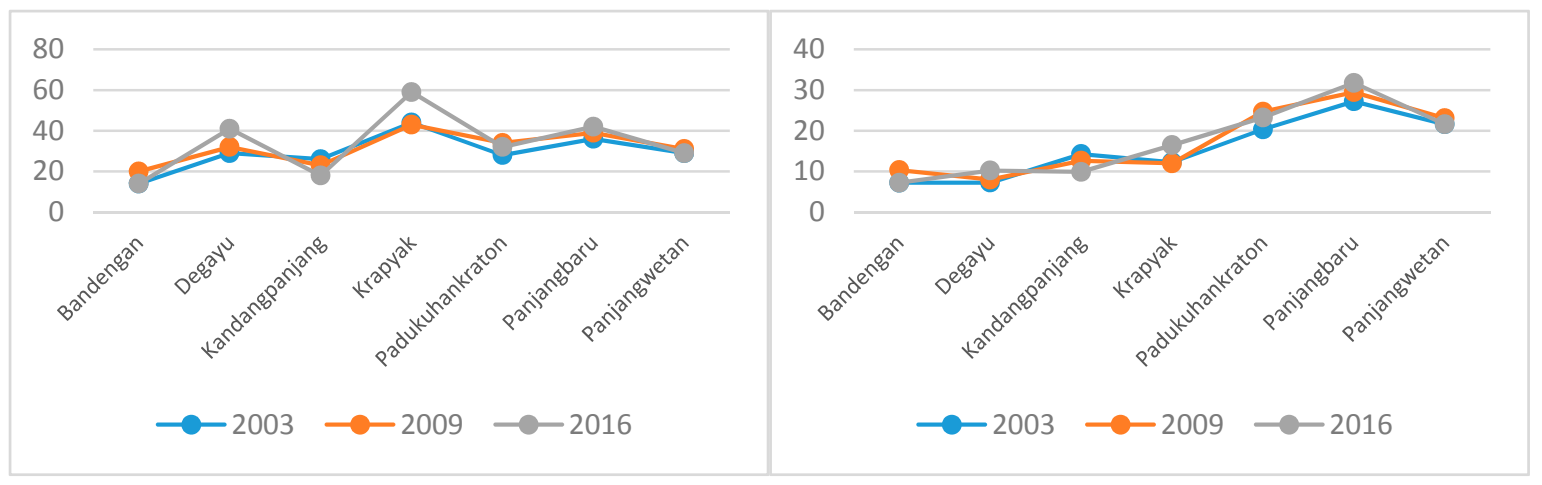

(a)

(b)

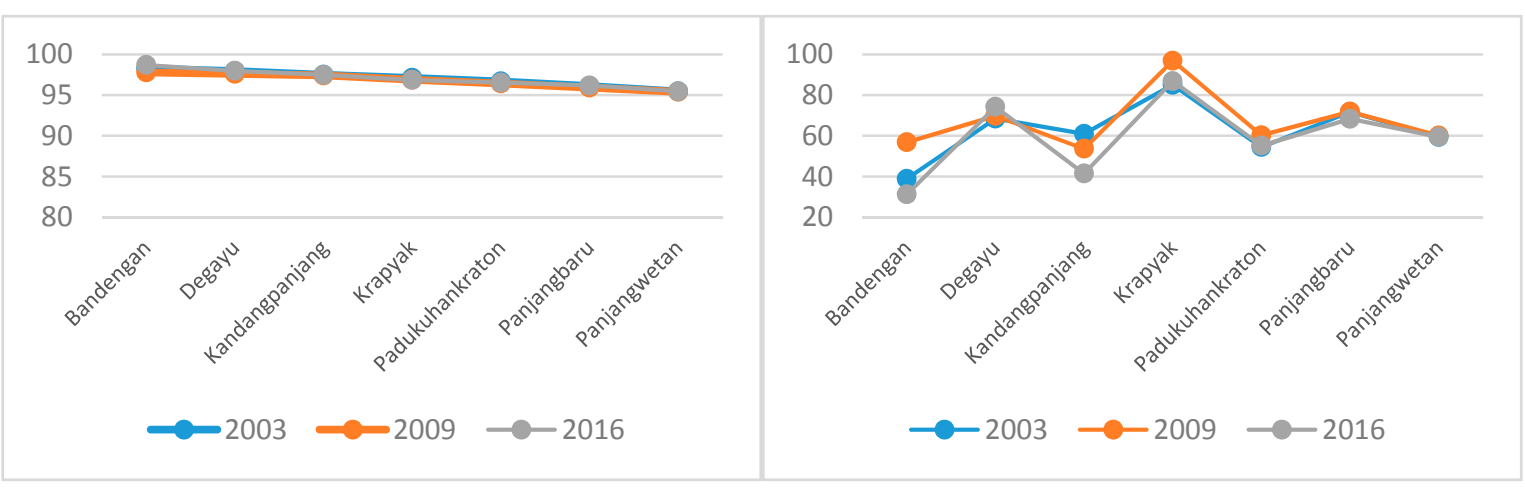

(c)

(d)

Figure 4. Aggregation pattern metric dynamics in each villages, (a) Number of Patch, (b) Patch Density, (c) Percentage of Like Adjacencies, (d) Interspersion and Juxtaposition Index

From the results of spatial metric analysis can be seen that every village in the coastal area of Pekalongan have different metric aggregation values. This is in accordance with the characteristics of land use patterns in each village. The area with the highest NP value is Krapyak with a value that always rises every period, in the period 2016 value reached 59 patches. Then for area with the smallest NP value in each period is in Bandengan. For PD value, the highest of each period is Panjang Baru 
with period value of 2016 is 31,76 patch/100 ha. The smallest PD value is in the Bandengan. For PLADJ values tend to be the same in the range of $95-98 \%$ with the highest value in Bandengan and the lowest in Panjang Wetan. Then for IJI value, the highest value of each period is in Krapyak and lowest in Bandengan.

\subsection{Diversity Pattern Metric}

The next spatial pattern that is analyzed is related to the level of diversity of land use in coastal area of Pekalongan. This analysis uses spatial metrics for the category of diversity in the landscape level calculated in the periods of 2003, 2009, and 2016 for known urban growth of diversity level dynamics. Level of expansion in coastal area of Pekalongan can be justified from diversity which is its own characteristic for the region due to sea level rise factor. Metric diversity used is Shannon's Diversity Index (SHDI) and Shannon's Evenness Index (SHEI). The statistics of the diversity are shown in Figure 5 below.

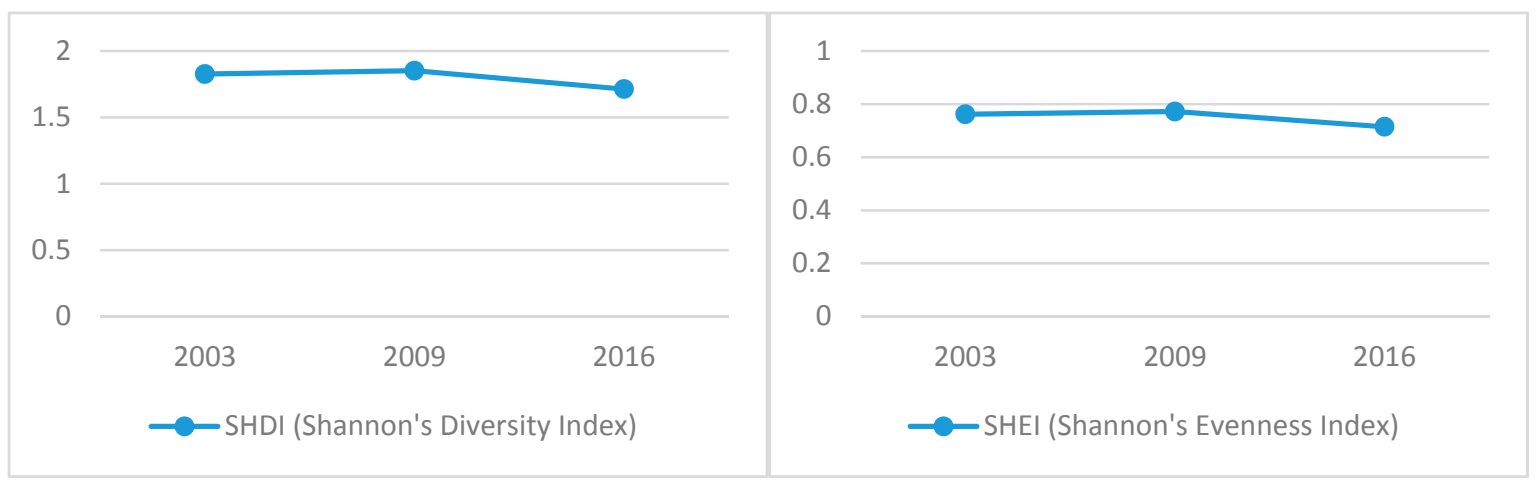

(a)

(b)

Figure 5. Diversity pattern metric dynamics in landscape, (a) Shannon's Diversity Index, (b) Shannon's Evenness Index

SHDI and SHEI metric values change for each year period but not significant. The change in value indicates the dynamics of regional development as measured by the diversity of land use. The value of SHDI experiencing fluctuating dynamics, in the period 2003 to 2009 experienced a relatively low increase of 0.02 which then in the period of 2009 to 2016 decreased by 0.14 . SHDI is a metric calculation of land use diversity index at landscape level showing the pattern of development of land use. The higher of the value of SHDI indicates the value of diversity is also greater and indicates increased urban growth. Then for the value of SHEI has the same fluctuation with SHDI. In the period of 2009 has a value of SHEI of 0.7722 and decreased to the period 2016 to 0.7148 . SHEI is a metric measurement of the level of evenness of patch diversity with the proportion of different types of land use. The smaller SHEI value means the even distribution of events between different types of land use patches. The value of diversity in coastal areas of Pekalongan as a whole is interpreted from the value of SHDI and SHEI. Every village in the coastal area of Pekalongan also has its own expansion trend. Here for the calculation of diversity in each village. 


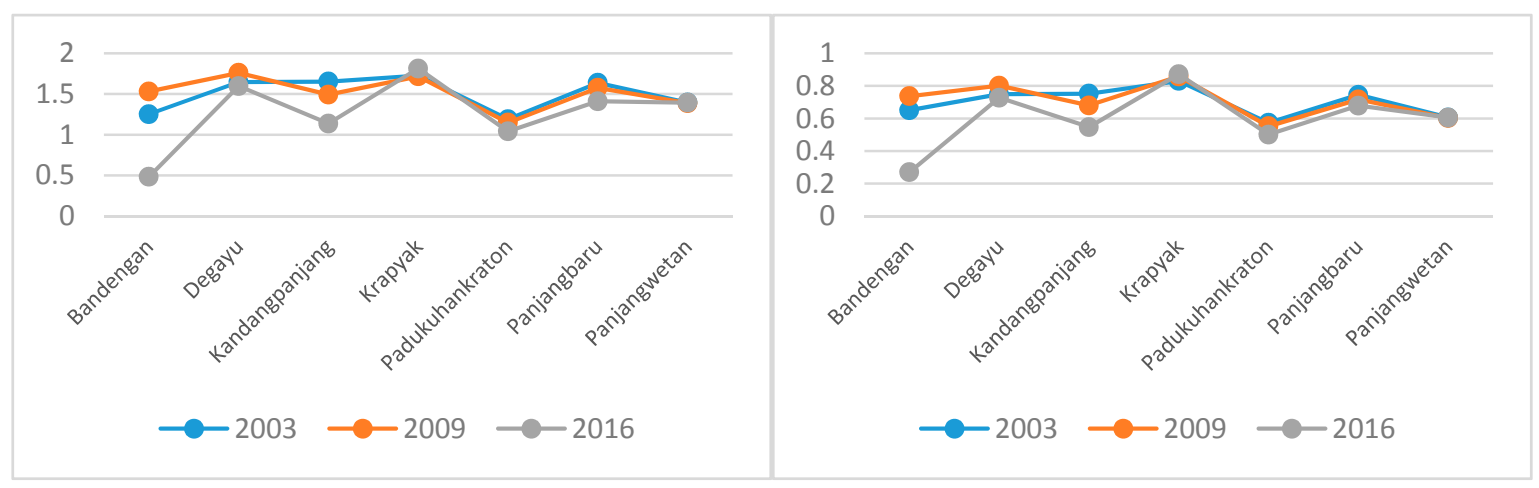

(a)

(b)

Figure 6. Diversity pattern metric dynamics in each villages, (a) Shannon's Diversity Index, (b) Shannon's Evenness Index

Based on the calculation of spatial metrics can be seen that the highest SHDI value per period is in Krapyak with the value in the period 2016 reached 1.8133. Then for the lowest SHDI value is in Bandengan, and has a significant decrease in the period of 2009 to 2016 amounted to 1.05. SHEI value statistics are almost as fluctuate as SHDI values. The highest SHEI value is at Krapyak and the lowest in Bandengan. Level of land use growth of each region in the coastal area of Pekalongan is indicated based on the value of diversity in each region in the period 2003 to 2016.

\section{Discussion}

The spatial pattern analysis of land use by using spatial approach metric statistics above show the spatial patterns on 2 (two) categories: aggregation and diversity of land use at the landscape level, in Pekalongan's coastal area. Each metric that is used shows the calculation of various spatial facets where the results indicate the pattern of density and diversity in coastal areas of Pekalongan. Spatial metric is an appropriate approach in analyzing the structure and composition of a landscape. Based on simulation result of spatial metric analysis for every metric aggregation that used majority indicate that in coastal area of Pekalongan for every period of year always experience degradation value of land use aggregation and more fragmented.

Metric NP and PD are patch compositions in Landscape for indicators of fragmentation levels [29]. The higher the value of NP and PD the higher the value of the fragmentation that makes the density level decreases. In the coastal region of Pekalongan, the NP value always rises over each period, indicating an increase in fragmentation that makes the density level decrease, as in previous studies related to NP [30][31][32]. Then PD metric is related to the NP, and in the coastal area of Pekalongan, PD value always decreased. It also indicates the increasing fragmentation occurring in the area [33][34][35][36]. Next comes the results of PLADJ and IJI metrics which are indicative of patch configuration [29]. The value of PLADJ shows the level of density as related to previous PLADJ studies [32][37]. In the area affected by sea level rise, PLADJ value experienced relatively small fluctuations, but overall decreased in value in the period 2003-2016. Then IJI values show fragmentation levels [38][33]. The value of IJI in coastal areas of Pekalongan shows that value always decreases.

Most of the metric of aggregation indicate that land use density level of Pekalongan's coastal area has decreased periodically, which is caused by a fragmentation. This condition led to the increase of its urban sprawl level. As the urban sprawl level of Pekalongan's coastal area is growing higher, the driving force of land use change is associated with impact of sea level rise. Krapyak is the area with the highest sprawl level based on the spatial metric calculation, where the patch composition and configuration increased on each period. Then the diversity index of Pekalongan's coastal area could be known from the spatial metric analysis for land use diversity category with the SHDI and SHEI parameter. The level of diversity shows the landscape growth level. As the land use diversity 
increase, the growth level follows because of a new development that form a diverse region, vice versa.

The calculation of SHDI and SHEI in coastal areas of Pekalongan has been up and down in every period. For the period of 2003 to 2009, SHDI and SHEI values have an increased value but with a small value. This condition indicates that during that period the area was not massively developed according its land use composition and configuration. And then on next period, 2009 to 2016, the SHDI and SHEI level decreased, which means that the growth level of Pekalongan's urban area is getting lower. This is as research related to SHDI in an existing region interprets the value of SHDI [34][38][39][40]. The higher the SHEI value, indicating the more uniform proportion of the distribution of land use type patches as related to the use of SHEI [39][35]. And from the analysis can be known the development of land use in coastal areas of Pekalongan tend to be static and decreased during the period of 2009-2016. It may also be associated with the phenomenon of sea level rise in the form of floods that hit the coastal region of Pekalongan from 2010 onwards. For the most stagnant urban areas in coastal Pekalongan is in Bandengan with the most significant decline in the period 2009 to 2016. Bandengan is the village with the most severe sea level rise on the coastal area of Pekalongan.

The result shows that in 2003, 2009, and 2016 the coastal area of Pekalongan has experienced dynamics spatial pattern. The land use density level in each period always decrease, which also means that the sprawl level is getting higher at a relative low growth level. Generally there are 3 (three) types of urban sprawl, which are concentric development, ribbon development, and leap frog development [5]. Based on the characteristic of land use change dynamic, the development of Pekalongan's coastal area is tend to the ribbon development pattern, since the level of aggregation and the compactness level has decreased periodically. The ribbon development itself could be identified as a condition where the compactness of landscape decrease [41]. In this case in accordance with the calculation results of spatial metric analysis that shows the level of aggregation and the decline in the value of the solidarity in Pekalongan coastal region. Low levels of regional development can be assumed because of the impact of tidal flood which are negative externalities [5].

Based on the sprawl indication that occurred in the coastal area of Pekalongan, other indicators could be proven through further research. Since the main focus of the research is to discuss the sprawl from its patch composition and configuration, a further research that focus on the areas where sprawl is indicated, such as areas along the connector road, is possible. Sprawl as in ribbon development could be classified based on its land use that is fragmented by the road network. The process could be continued with a research that focus on the finding of relation between inundation caused by sea level rise and urban density pattern, including its impact. From this study case it could be questioned that whether the decreasing of compactness level is a loss either an impact of natural disaster. Subsequently, a recommendation for this research is to develop a model could predict the spatial pattern in the future according the dynamic trend of land use. Beside that, a policy plan that embrace this condition should be also considered in order to achieve the spatial vision of Pekalongan.

\section{Conclusions}

Based on the result, it could be concluded that the land use of Pekalongan's coastal area has experienced a high dynamics. Areas that are mostly impacted with the land use change as classified by its wide are paddy field and swamp areas. The result of spatial metrics indicates that the aggregation and diversity value of Pekalongan's coastal area decreased periodically with a small fluctuation. The spatial pattern of the coastal area's land use tend to be classified as ribbon development, which could be identified from its spatial pattern value that indicates the sprawl phenomenon. Thus, the expansion of urban area in Pekalongan's coastal area itself is lower due to the inundation which is caused by sea level rise.

Acknowledgments: This research was supported by Ministry of Research, Technology and Higher Education of the Republic of Indonesia through the student creativity program 2017 field of exact research. We would like to thank local goverment of Pekalongan who kindly allowed and help us to doing primary survey and give information data about study area. 
Author Contributions: Ali Wijaya conceived the project and analysed the data. Mohammad Hadikunnuha and Danika H. Nabila performed land use classification and collecting data. Azillatin Q. Diny and Rahel P. Pamungkas wrote the paper and editorial support. Ali Wijaya, Cahyono Susetyo, and Nursakti A. Pratomoatmojo designed the experiments.

Conflicts of Interest: The authors declare no conflict of interest. The founding sponsors had no role in the design of the study; in the collection, analyses, or interpretation of data; in the writing of the manuscript, and in the decision to publish the results.

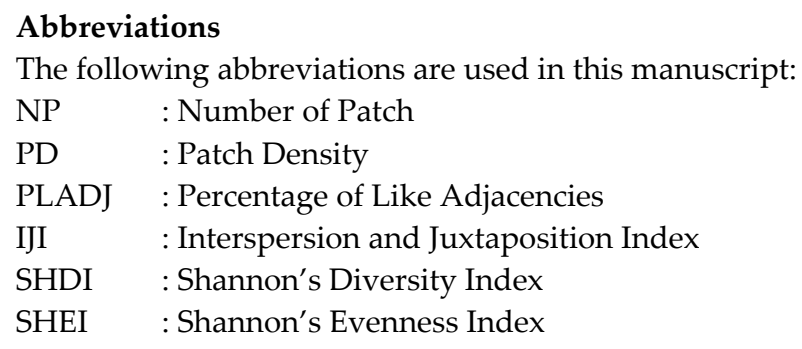

\section{References}

1. E. J. Gustafson, “Minireview: Quantifying Landscape Spatial Pattern: What Is the State of the Art?,” Ecosystems, vol. 1, no. 2, pp. 143-156, 1998.

2. M. Herold, H. Couclelis, and K. C. Clarke, "The Role of Spatial Metrics In The Analysis and Modeling of Urban Land Use Change," Comput. Environ. Urban Syst., vol. 29, no. 4, pp. 369-399, 2005.

3. K. Al-ahmadi, L. See, A. Heppenstall, and J. Hogg, "Calibration of A Fuzzy Cellular Automata Model of Urban Dynamics in Saudi Arabia," Ecol. Complex., vol. 6 (2), pp. 80-101, 2008.

4. M. Fuglsang, B. Munier, and H. S. Hansen, "Modelling Land-use Effects of Future Urbanization Using Cellular Automata: An Eastern Danish case," Environ. Model. Softw., vol. 50, pp. 1-11, 2013.

5. H. S. Yunus, Spatial Structure of The Urban, 1st ed. Yogyakarta: Pustaka Pelajar, 1999.

6. Y. Murayama and R. B. Thapa, Spatial Analysis and Modeling in Geographical Transformation Process, 100th ed., vol. 100. Japan: Springer Science+Business Media, 2011.

7. S. Koukoulas, A. T. Vafeidisa, G. Vafeidis, and E. Symeonakis, "The Role of Spatial Metrics on the Performance of an Artificial Neural-Network Based Model for Land Use Change," Int. Arch. Photogramm. Remote Sens. Spat. Inf. Sci., vol. XXXVII Par, pp. 1661-1666, 2008.

8. JawaPos.com, “Banjir Makin Parah, Pemkot Pekalongan Siapkan Pengungsian," 2016. [Online]. Available: http://www.jawapos.com/read/2016/05/30/31213/banjir-makin-parah-pemkot-pekalongan-siapkanpengungsian-/2. [Accessed: 03-Jan-2017].

9. S. Widada, "Symptoms of Sea Water Intrusion in Pekalongan City Beach Area," Ilmu Kelaut. UNDIP, vol. 12, no. 1, pp. 45-52, 2007.

10. S. Nashrrullah, Aprijanto, J. M. Pasaribu, M. K. Hazarika, and L. Samarakoon, “Study on Flood Inundation in Pekalongan, Central Java," Int. J. Remote Sens. Earth Sci., vol. 10, no. 2, pp. 76-83, 2013.

11. Radar Pekalongan, "Cari Solusi Rob hingga ke Belanda," 2017. [Online]. Available: http://radarpekalongan.com/87229/cari-solusi-rob-hingga-ke-belanda/. [Accessed: 09-Apr-2017].

12. H. Prihatno, "Variation of Sea Level Rise in Pekalongan Coastal Area, From Tidal and Wind Analysis," J. Segara, vol. 8, pp. 27-34, 2012.

13. Diez et al, “Urban Coastal Flooding and Climate Change," J. Coast. Res., vol. SI 64, pp. 205-209, 2011.

14. M. A. Marfai, D. Mardianto, A. Cahyadi, F. Nucifera, and H. Prihatno, "Spatial Modeling The Hazard of Tidal Flood Based on Climate Change Scenario and Its Impact on Pekalongan's Coastal," J. Bumi Lestari, vol. 13, no. 2, pp. 244-256, 2013.

15. Burgi et al, "Driving Force of Landscape Change-Current and New Directions," Landsc. Ecol., vol. 19, pp. 857-868, 2004.

16. A. A. Nugroho, "Land Use Change Modelling Under Sea Level Rise and Maximum Tide in Lamong Bay (PUTL) Part of Surabaya," Institut Teknologi Sepuluh Nopember, 2013.

17. Statistics of Pekalongan, Pekalongan City in Figures 2016, 2016th ed. Pekalongan, 2016.

18. R. Shofiana, P. Subardjo, and I. Pratikto, "Analysis of Land Use Change in Coastal Area of Pekalongan City Using Landsat Data 7 Etm +," J. Mar. Res., vol. 2, no. 3, pp. 35-43, 2013. 
19. G. Chust et al., "Human Impacts Overwhelm The Effects of Sea Level Rise on Basque Coastal Habitats (N Spain) Between 1954 and 2004," Estuar. Coast. Shelf Sci., vol. 84, no. 4, pp. 453-462, 2009.

20. M. . Marfai, N. . Pratomoatmojo, T. Hidayatullah, A. W. Nirwansyah, and M. Gomareuzzaman, Coastal Vulnerability Model Based on Coastal and Tide Flow Changes (Case Study: Coastal Area of Pekalongan), 1st ed. Yogyakarta: Universitas Gadjah Mada, 2011.

21. N. A. Pratomoatmojo, "Land Use Change Modelling Under Tidal Flood Scenario by Means of Markov Cellular Automata in Pekalongan Municipal," Universitas Gadjah Mada, 2012.

22. H. S. Yunus, Urban Management in Spatial Perspective. Yogyakarta, 2005.

23. Wikipedia, “Kota Pekalongan,” 2016. [Online]. Available: https://id.wikipedia.org/wiki/Kota_Pekalongan. [Accessed: 02-Feb-2017].

24. N. Anggraini, B. Trisakti, and E. Budhi, "Application of Sattelite Data To Analyze Inundation Potential and the Impact of Sea Level Rise," J. Penginderaan Jauh, vol. 9, no. 2, pp. 140-151, 2012.

25. K. McGarigal, Fragstats Help. Amherst: University of Massachusetts, 2015.

26. D. W. S. W. Jay Lee, “Statistical Analysis With ArcView GIS,” p. 192, 2001.

27. J. P. Reis, E. A. Silva, and P. Pinho, "Spatial Metrics to Study Urban Patterns In Growing and Shrinking Cities," Urban Geogr., vol. 3638, no. October, pp. 1-26, 2015.

28. K. McGarigal, S. A. Cushman, M. C. Neel, and E. Ene, "FRAGSTATS v4: Spatial Pattern Analysis Program for Categorical and Continuous Maps," Univ. Massachusettes, Amherst, MA. URL http//www.umass.edu/landeco/research/fragstats/fragstats.html, no. 2007, 2012.

29. D. Rutledge, "Landscape Indices as Measures of The Effects of Fragmentation: Can Pattern Reflect Process ?," DOC Sci. Intern. Ser. 98, pp. 1-27, 2003.

30. H. M. Pham, Y. Yamaguchi, and T. Q. Bui, "A Case Study On The Relation Between City Planning and Urban Growth Using Remote Sensing and Spatial Metrics," Landsc. Urban Plan., vol. 100, pp. 223-230, 2011.

31. N. H. K. Linh, S. Erasmi, and M. Kappas, "Quantifying Land Use/Cover Change and Landscape Fragmentation in Danang City, Vietnam: 1979-2009," Int. Arch. Photogramm. Remote Sens. Spat. Inf. Sci., vol. XXXIX-B8, no. September, pp. 501-506, 2012.

32. T. V. Ramachandra, H. A. Bharath, and M. V. Sowmyashree, "Urban Footprint of Mumbai - The Commercial Capital of India," J. Urban Reg. Anal., vol. 6, no. 1, pp. 71-94, 2014.

33. C. Pang, H. Yu, J. He, and J. Xu, "Deforestation and Changes in Landscape Patterns from 1979 to 2006 in Suan County, DPR Korea," Forests, vol. 4, no. 4, pp. 968-983, 2013.

34. R. B. Thapa and Y. Murayama, "Examining Spatiotemporal Urbanization Patterns in Kathmandu Valley, Nepal: Remote Sensing and Spatial Metrics Approaches," Remote Sens., vol. 1, no. 3, pp. 534-556, 2009.

35. Y. C. Weng, "Spatiotemporal Changes of Landscape Pattern In Response to Urbanization," Landsc. Urban Plan., vol. 81, no. 4, pp. 341-353, 2007.

36. 36. C. Sun, Z. F. Wu, Z. Q. Lv, N. Yao, and J. B. Wei, “Quantifying Different Types of Urban Growth and The Change Dynamic In Guangzhou Using Multi-Temporal Remote Sensing Data," Int. J. Appl. Earth Obs. Geoinf., vol. 21, no. 1, pp. 409-417, 2012.

37. 37. P. Minh Hai and Y. Yamaguchi, "Characterizing the Urban Growth From 1975 to 2003 of Hanoi City Using Remote Sensing and A Spatial Metric," vol. 21, no. 2, pp. 104-110, 2007.

38. P. M. Torrens, "A Toolkit for Measuring Sprawl," Appl. Spat. Anal. Policy, vol. 1, no. 1, pp. 5-36, 2008.

39. H. Cao et al., "Urban Expansion and Its Impact On The Land Use Pattern In Xishuangbanna Since The Reform and Opening Up of China," Remote Sens., vol. 9, no. 2, pp. 1-21, 2017.

40. T. Pah, R. Syed, H. Ismail, T. S. Hussain, and H. Ismail, "Land Use Changes Analysis for Kelantan Basin Using Spatial Matrix Technique 'Patch Analyst' in Relation to Flood Disaster," J. Techno-Social, vol. 3, no. 1, 2011.

41. F. Aguilera, L. M. Valenzuela, and A. Botequilha-Leitão, "Landscape Metrics In The Analysis of Urban Land Use Patterns: A Case Study In A Spanish Metropolitan Area," Landsc. Urban Plan., vol. 99, no. 3-4, pp. 226-238, 2011. 